\title{
Thermal inactivation of weed seeds and tubers during drying of pig manure
}

\author{
C.M.J. BLOEMHARD ${ }^{1}$, M.W.M.F. ARTS ${ }^{2}$, P.C. SCHEEPENS ${ }^{1}$ \& A.G. ELEMA ${ }^{3}$ \\ ${ }^{1}$ DLO-Centre for Agrobiological Research (CABO-DLO), P.O. Box 14, NL 6700 AA \\ Wageningen, Netherlands \\ ${ }^{2}$ DLO-Institute of Agricultural Engineering (IMAG-DLO), P.O. Box 43, NL 6700 AA \\ Wageningen, Netherlands \\ ${ }^{3}$ Research Station for Arable Farming and Field Production of Vegetables (PAGV), P.O. \\ Box 430, NL 8200 AK Lelystad, Netherlands
}

Received: 17 May 1991; accepted: 25 November 1991

\begin{abstract}
Propagules of seven plant species were subjected to heat treatments comparable to industrial manure processing. Propagules of all species, which had been preincubated 1 day in pig slurry, responded to heat treatment in an oven in the range from 50 to $104{ }^{\circ} \mathrm{C}$. Brassica napus and Solanum nigrum were the most heat-sensitive species. The viability of their seeds was greatly reduced after $15 \mathrm{~min}$ at $50^{\circ} \mathrm{C}$. Seeds of Amaranthus retroflexus, B. napus, Chenopodium album, and $S$. nigrum were inactivated after $3 \mathrm{~min}$ at $75^{\circ} \mathrm{C}$, seeds of Echinochloa crus-galli and tubers of Cyperus esculentus after $3 \mathrm{~min}$ at $90^{\circ} \mathrm{C}$, whereas seeds of Abutilon theophrasti only slightly responded to $3 \mathrm{~min}$ at $104{ }^{\circ} \mathrm{C}$. Heating seeds of $A$. theophrasti at $104{ }^{\circ} \mathrm{C}$ with steam resulted in much less viability than heating at the same temperature in the oven. More than 1 day preincubation in slurry positively affected thermal inactivation of $E$. crus-galli seeds and $C$. esculentus tubers at $75^{\circ} \mathrm{C}$, but not of $A$. theophrasti seeds at 75,90 , and $104{ }^{\circ} \mathrm{C}$.
\end{abstract}

Keywords : weed propagules, viability, thermal inactivation, heat-sensitivity, imbibition, manure processing

\section{Introduction}

Slurry is a surplus product in some regions in the Netherlands with intensive livestock farming. The excess of nutrients in the slurry contributes to the pollution of soil, water, and atmosphere. The surplus problem may partially be solved by utilizing the slurry as an organic fertilizer for crops on arable land in other regions. The risk that slurry contains viable weed propagules (seeds and vegetative reprocution organs) is an important factor that restricts its use in regions with arable farming. Weeds that are dominant in regions with livestock farming, such as Echinochloa crus-galli, and herbicide-resistant biotypes of Chenopodium album and Solanum nigrum, will probably increase weed control costs if they became 
established in regions with arable farming. The same is true for weed species that are not yet widely distributed in regions with livestock farming, but still absent in regions with arable farming. These species include Abutilon theophrasti, Amaranthus retroflexus, and Cyperus esculentus. Fodder with weed propagules may be fed to farm animals (Elema et al., 1990). The propagules can survive subsequent passage through the digestive tract of farm animals (Atkeson et al., 1934; Burton \& Andrews, 1948), and retain their viability during exposure to slurry (Rieder, 1966; Takabayashi et al., 1979; Elema et al., 1990).

To facilitate transportation of manure over large distances, technologies have been developed that remove water from slurry. A process that several of these technologies have in common is the drying stage, in which the water content of an intermediate product is decreased to about $15 \%$ by heat treatment. This heat treatment may inactivate viable weed propagules that are present in the intermediate product. In addition to the effects of heat treatment, friction forces involved in pelleting the intermediate product have a detrimental effect onf the viability of the weed propagules (C.M.J. Bloemhard, unpublished results).

Dry seeds may be quite resistant to heat. For instance, $94 \%$ of seeds of Avena fatua were still viable after heating 1 hour at $100{ }^{\circ} \mathrm{C}$ in an oven, whereas all seeds were dead only after heating 1 hour at $140{ }^{\circ} \mathrm{C}$ (Metz, 1970). Maun (1977) found similar results for seeds of E. crus-galli and Poa pratensis. Hopkins (1936) imbibed weed seeds at $25{ }^{\circ} \mathrm{C}$ and $50 \%$ relative humididy ( $\mathrm{RH}$ ) before heating them 15 minutes in closed tubes. Under these conditions, the lethal temperature for seeds of $A$. fatua was $105^{\circ} \mathrm{C}$, for seeds of $C$. album $95^{\circ} \mathrm{C}$, and for seeds of $A$. retroflexus and Thlaspi arvensis $85^{\circ} \mathrm{C}$. Horowitz \& Taylorson (1984) heated seeds of $A$. theophrasti 1 hour, and found a decrease in the germination rate at $70{ }^{\circ} \mathrm{C}$ and higher temperatures. The effect of heat was larger if the seeds were heated at high $\mathrm{RH}$ than in a dry atmosphere. Immersion in hot water was more effective than dry or humid heat. Under all these conditions, the seeds had lost their viability after treatment at $100{ }^{\circ} \mathrm{C}$. Thermal inactivation was preceded by breaking of dormancy at temperatures of $70{ }^{\circ} \mathrm{C}$ and higher. From the available data it can be concluded that the effect of heat treatment on seeds is greatly affected by the moisture content of the seeds, and/or moisture in the environment.

Aim of our investigations was to measure the effect of heat treatments on weed propagules under circumstances that are comparable to those in experimental plants for manure processing. We assumed that weed propagules will have imbibed at least 1 day in the slurry before processing. The intermediate product may be heated at $130-150^{\circ} \mathrm{C}$ for at least 1 hour. Other heating processes are feasible with temperatures between $75^{\circ} \mathrm{C}$ and just above $100{ }^{\circ} \mathrm{C}$, and a duration of heat treatment of 15 minutes at the utmost.

Our experiment were done under laboratory conditions with pig manure. In addition to the six weed species mentioned in the introduction, Brassica napus (a crop species) was included to represent cruciferous weeds with oil-containing seeds. 


\section{Materials and methods}

\section{Seeds and tubers; manure}

Seeds of Abutilon theophrasti Med. were imported from the USA in 1985. Seeds of Amaranthus retroflexus L., Chenopodium album L., Echinochloa crus-galli (L.) Beauv., and Solanum nigrum L., and tubers of Cyperus esculentus L. were collected in the vicinity of Wageningen in 1988 and 1989. After collection, the seeds and tubers were dried at room temperature and stored under dry conditions at $4{ }^{\circ} \mathrm{C}$. Seeds of Brassica napus L. were commercially available.

The pig slurry used for preincubation of seeds and tubers contained $3.2 \%$ inorganic and $6.4 \%$ organic dry matter. The intermediate product from one of the experimental manure processing plants used for the heat treatments of seeds and tubers contained $24 \%$ inorganic and $37 \%$ organic dry matter.

\section{Measuring the vitality of seeds and germination of tubers}

The viability of seeds was estimated by measuring their vitality with the tetrazolium test (MacKay, 1972). Seeds that felt softly were regarded as non-vital. The other seeds were placed between moist blotting paper for 18 hours. After piercing the seed-coat with a needle, the seeds were put into a solution of $1 \% 2,3,5-$ trifenyltetrazoliumchloride (TTC), and stored 48 hours at $30^{\circ} \mathrm{C}$ in the dark. To determine the vitality of the seeds, the colouring of the seed embryos was examined. A seed was considered to be vital if more than half of the embryo was red, or if the whole embryo was pale red. They were considered to be non-vital if more than half of the embryo was uncoloured, or if the embryo was coloured only pinkish.

Tubers of $C$. esculentus have no embryo. Their viability was measured in a germination test. Tubers were placed on blotting paper moistened with water in Petri dishes and incubated during 4 weeks at alternating temperatures of $15^{\circ} \mathrm{C}$ for 10 hours in the dark and $25^{\circ} \mathrm{C}$ for 14 hours in the light.

During the experiments, the germinal force of untreated tubers of $C$. esculentus was about $80 \%$, and the vitality of untreated seeds ranged from 95 to $100 \%$ for all species.

\section{Realization of heat treatments in an oven and in a pressure vessel}

After incubation in pig slurry, the seeds and tubers were exposed to various temperatures in a convection oven (GFL, type 7106) or in a pressure vessel (toaster). The maximal deviation from the desired temperature in the oven was $1.5^{\circ} \mathrm{C}$; deviation from the mean temperature was $0.5^{\circ} \mathrm{C}$. Relative humidity in the oven varied from $4 \%$ at $75^{\circ} \mathrm{C}$ to less than $1 \%$ at $95 \%$.

In the oven, glass pots of 0.51 with $75 \mathrm{~g}$ of the intermediate product were placed in a buffer of sand. A polyester mesh filter ( $\varnothing 83 \mathrm{~mm}$, height $50 \mathrm{~mm}$ ) was put on top of the manure. The lids of the pots were closed, and the pots conditioned 24 
hours at the heating temperature. The pots were then opened, the seeds or tubers were placed in the polyester mesh filter and covered with a preheated stainless steel plate $(425 \mathrm{~g})$. The purpose of the steel plate was to ensure rapid heat transmission to the seeds and tubers (cf. Scherer \& Kutzbach, 1980). In most of the experiments, the lids of the pots remained open during the subsequent heat treatments of the seeds and tubers. One pot, containing seeds or tubers of one species, was treated at a time. All treatments at one temperature of one replicate were done on a single day.

In the toaster, seeds and tubers were heated with saturated steam. Seeds and tubers in polyester mesh bags were placed in a perforated cilinder of metal. The cilinder was placed in the toaster $(\varnothing 260 \mathrm{~mm}$, height $780 \mathrm{~mm})$. The pressure was set at $116 \mathrm{kPa}$ (abs.), corresponding with a temperature of $104{ }^{\circ} \mathrm{C}$. After the treatment, the steam was blown off rapidly. No manure was present in the toaster. Seeds and tubers for one replicate were treated together.

\section{Experimental design}

Four different experiments were done, Experiments 1, 2 and 3 with no replicates, and Experiment 4 with three replicates. Each treatment was carried out with 50 seeds or tubers of the species involved in the respective experiment.

In Experiment 1, the effect of heat treatments on the viability of seeds or tubers was tested for the seven mentioned species, with temperature and heating time as variables. All the seeds and tubers were preincubated 1 day in pig slurry.

In Experiment 2, the effect of humidity of ambient air on the viability of seeds and tubers of the seven species was tested. Pots with seeds or tubers were treated 3 or 6 minutes at $75^{\circ} \mathrm{C}$ while the pots were open ('low' humidity) or closed ('high' humidity). The humidity in the closed pots was not measured. Again, all the seeds and tubers were preincubated 1 day in pig slurry. Differences in results were analysed separately for $A$. theophrasti, C. esculentus and E. crus-galli. The logits of the viability percentages were taken and tested with Chi-square.

In Experiment 3, the effect of preincubation duration on viability of seeds of $A$. theophrasti, $A$. retroflexus, and E. crus-galli, and tubers of $C$. esculentus was tested. Seeds and tubers were preincubated 1 or 10 days in pig slurry before the heat treatment. Thereafter, they were 3 minutes heated at $75^{\circ} \mathrm{C}$. Differences in viability percentages for $A$. theophrasti, $C$. esculentus, and $E$. crus-galli were tested with Chi-square.

In Experiment 4, three factors were investigated with seeds of $A$. theophrasti, $A$. retroflexus, E. crus-galli, and tubers of $C$. esculentus: duration of preincubation in pig slurry, height of temperature, and duration of heat treatment. In addition, for the heat treatments at $104{ }^{\circ} \mathrm{C}$, two methods (oven and toaster) were compared. After testing for homogeneity and normal distribution with the Cochran- and Barlett-test, differences for $A$. theophrasti were tested with ANOVA. Differences for $C$. esculentus and E. crus-galli for the treatments at $75^{\circ} \mathrm{C}$ were tested with Chi-square, using logits of the percentages. 


\section{Results}

None of the seeds and tubers of the seven species survived a heat treatment during 1 hour at $130{ }^{\circ} \mathrm{C}$. The other results of Experiment 1 are presented in Table 1 . In general, the higher the temperature, and the longer the duration of the heat treatment, the less propagules remained viable, but large differences were found between the species. The species are ranked according to their heat resistance, with $B$. napus and $S$. nigrum being the most sensitive species, and $A$. theophrast $i$ the most resistant one. Only the ranking of $A$. retroflexus was not quite clear from the experimental results. Seeds of this species tended towards a decrease in viability after the treatments of $50^{\circ} \mathrm{C}$, none were viable after 3 and 9 minutes at $75{ }^{\circ} \mathrm{C}$, but $45 \%$ was viable after 15 minutes at $75^{\circ} \mathrm{C}$. It should be mentioned that in the latter case the pot with manure and seeds had unintentionally been closed before the heat treatment. In the subsequent experiments, there was not even a tendency that seeds of $A$. retroflexus could survive any heat treatment at $75^{\circ} \mathrm{C}$ (cf. Tables 2-4).

A factor that is influenced by closing the pots is the humidity of the ambient air. In Experiment 2, the influence of this factor was investigated for propagules of the seven species (Table 2). Seeds of $B$. napus, $S$. nigrum and $C$. album again did not survive any of the treatments at $75^{\circ} \mathrm{C}$. In this experiment, all the seeds of $A$. retroflexus were non-viable after the treatments at 'high' $\mathrm{RH}$ (closed pots) as well as 'low' RH (open pots). The RH of the ambient air only had a significant effect on the viability of the seeds of E. crus-galli (average of 3 and 6 minutes heat duration): less seeds were viable after treatment at 'high' RH than at 'low' RH. The duration of the heat treatment at $75^{\circ} \mathrm{C}$ also had an effect on the seeds of $E$. crus-galli.

In Experiment 3, the influence of the preincubation time of seeds and tubers in slurry prior to 3 minutes heat treatment at $75^{\circ} \mathrm{C}$, was investigated. The experi-

Table 1. Viability (\%) of seeds and tubers of seven plant species after 3, 9, and 15 minutes heating in an oven at 50,75 , and $100^{\circ} \mathrm{C}$. Seeds and tubers were 1 day preincubated in pig slurry.

\begin{tabular}{|c|c|c|c|c|c|c|c|c|c|c|}
\hline \multirow[t]{2}{*}{ Species } & \multirow{2}{*}{$\begin{array}{l}\text { Temperature }\left({ }^{\circ} \mathrm{C}\right) \\
\text { Heat duration (min) }\end{array}$} & \multicolumn{3}{|l|}{50} & \multicolumn{3}{|l|}{75} & \multicolumn{3}{|c|}{100} \\
\hline & & 3 & 9 & 15 & 3 & 9 & 15 & 3 & 9 & 15 \\
\hline Brassica napus & & 92 & 78 & 0 & 0 & 0 & 0 & 0 & 0 & 0 \\
\hline Solanum nigrum & & 98 & 98 & 8 & 0 & 0 & 0 & 0 & 0 & 0 \\
\hline Amaranthus retroflexus & & 100 & 82 & 63 & 0 & 0 & 45 & 0 & 0 & 0 \\
\hline Chenopodium album & & 91 & 92 & 90 & 0 & 0 & 0 & 0 & 0 & 0 \\
\hline Echinochloa crus-galli & & 98 & 94 & 98 & 69 & 60 & 2 & 0 & 0 & 0 \\
\hline Cyperus esculentus & & 88 & 75 & 85 & 43 & 83 & 45 & 0 & 0 & 0 \\
\hline Abutilon theophrasti & & 90 & 90 & 88 & 82 & 77 & 73 & 65 & 70 & 54 \\
\hline
\end{tabular}


Table 2. Effect of humidity of ambient air on viability (\%) of seeds and tubers after 3 and 6 minutes heating at $75^{\circ} \mathrm{C}$. Seeds and tubers were preincubated 1 day in pig slurry. Differences for Abutilon theophrasti, Cyperus esculentus, and Echinochloa crus-galli were tested with Chi-square, using logits of the percentages.

\begin{tabular}{|c|c|c|c|c|c|}
\hline \multirow[t]{2}{*}{ Species } & \multirow{2}{*}{$\begin{array}{l}\text { Humidity } \\
\text { Heat duration (min) }\end{array}$} & \multicolumn{2}{|c|}{ 'low' } & \multicolumn{2}{|c|}{ 'high' } \\
\hline & & 3 & 6 & 3 & 6 \\
\hline Brassica napus & & 0 & 0 & 0 & 0 \\
\hline Solanum nigrum & & 0 & 0 & 0 & 0 \\
\hline Amaranthus retroflexus & & 0 & 0 & 0 & 0 \\
\hline Chenopodium album & & 0 & 0 & 0 & 0 \\
\hline Echinochloa crus-galli & & 43 & 15 & 35 & 7 \\
\hline Cyperus esculentus & & 35 & 10 & 25 & 15 \\
\hline \multirow[t]{2}{*}{ Abutilon theophrasti } & & 35 & 42 & 34 & 34 \\
\hline & & \multicolumn{2}{|c|}{ humidity } & \multicolumn{2}{|c|}{ heat duration } \\
\hline E. crus-galli & & \multicolumn{2}{|c|}{$P \leq 0.05$} & \multicolumn{2}{|c|}{$P \leq 0.01$} \\
\hline C. esculentus & & \multicolumn{2}{|c|}{$P>0.05$} & \multicolumn{2}{|c|}{$P>0.05$} \\
\hline A. theophrasti & & \multicolumn{2}{|c|}{$P>0.05$} & \multicolumn{2}{|c|}{$P>0.05$} \\
\hline
\end{tabular}

ment was done with propagules of those four species that could survive the heat treatment at $75^{\circ} \mathrm{C}$ in one of the foregoing experiments.

Seeds of $A$. retroflexus again did not survive 3 minutes heating at $75{ }^{\circ} \mathrm{C}$ (Table $3)$. The preincubation time affected the viability of seeds of $E$. crus-galli and tubers of $C$. esculentus. The preincubation time did not influence the effect of subsequent heating on viability of seeds of $A$. theophrasti.

Experiment 4 was done with the same four species that were used in Experiment 3. Aim of this experiment was to establish or confirm the conditions that would

Table 3. Effect of preincubation time on viability (\%) of seeds and tubers after 3 minutes heating at $75^{\circ} \mathrm{C}$. Differences for Abutilon theophrasti, Cyperus esculentus, and Echinochloa crus-galli were tested with Chi-square.

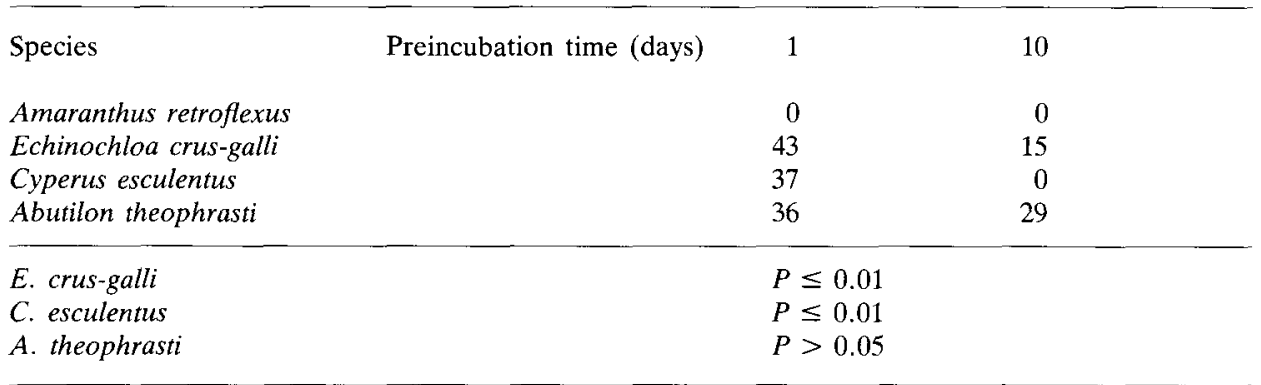


inactivate the seeds or tubers of these species.

Seeds of $A$. retroflexus again did not survive any of the heat treatments (Table 4). Seeds of E. crus-galli could survive heat treatment at $75^{\circ} \mathrm{C}$. The survival rate at this temperature decreased with increasing heat duration and increasing preincubation time. At temperatures above $75^{\circ} \mathrm{C}$, seeds of this species did not survive except for $1 \%$ in one case (at $104{ }^{\circ} \mathrm{C}$ ).

Table 4. Viability (\%) of seeds and tubers after 3 and 6 minutes heating in an oven at 75, 9090 and $104{ }^{\circ} \mathrm{C}$, and in a toaster at $104^{\circ} \mathrm{C}$. Seeds and tubers were 1,3 and 7 days preincubated in pig slurry. Differences between treatments for Abutilon theophrasti were tested with ANOVA. Differences between treatments at $75{ }^{\circ} \mathrm{C}$ for Cyperus esculentus and Echinochloa crus-galli were tested with Chi-square, using logits of the percentages.

Species

Heat duration (min)

Preincubation time (days)

\begin{tabular}{llllll}
3 & & & 6 & & \\
\cline { 4 - 5 } & 3 & 7 & 1 & 3 & 7
\end{tabular}

Amaranthus retroflexus

$\begin{array}{lr}\text { oven } & 75{ }^{\circ} \mathrm{C} \\ \text { oven } & 90{ }^{\circ} \mathrm{C} \\ \text { oven } & 104{ }^{\circ} \mathrm{C} \\ \text { toaster } & 104{ }^{\circ} \mathrm{C}\end{array}$

Echinochloa crus-galli

$\begin{array}{lr}\text { oven } & 75{ }^{\circ} \mathrm{C} \\ \text { oven } & 90{ }^{\circ} \mathrm{C} \\ \text { oven } & 104{ }^{\circ} \mathrm{C} \\ \text { toaster } & 104{ }^{\circ} \mathrm{C}\end{array}$

Cyperus esculentus

$\begin{array}{lr}\text { oven } & 75{ }^{\circ} \mathrm{C} \\ \text { oven } & 90{ }^{\circ} \mathrm{C} \\ \text { oven } & 104{ }^{\circ} \mathrm{C} \\ \text { toaster } & 104{ }^{\circ} \mathrm{C}\end{array}$

$\begin{array}{llllll}0 & 0 & 0 & 0 & 0 & 0 \\ 0 & 0 & 0 & 0 & 0 & 0 \\ 0 & 0 & 0 & 0 & 0 & 0 \\ 0 & 0 & 0 & 0 & 0 & 0\end{array}$

Abutilon theophrasti

$\begin{array}{lr}\text { oven } & 75{ }^{\circ} \mathrm{C} \\ \text { oven } & 90{ }^{\circ} \mathrm{C} \\ \text { oven } & 104{ }^{\circ} \mathrm{C} \\ \text { toaster } & 104{ }^{\circ} \mathrm{C}\end{array}$

Heating in oven, 75 against $90^{\circ} \mathrm{C}$

E. crus-galli

C. esculentus

A. theophrasti

Heating in oven, 90 against $104^{\circ} \mathrm{C}$

$\begin{array}{rrrrrr}51 & 11 & 0 & 21 & 8 & 1 \\ 0 & 0 & 0 & 0 & 0 & 0 \\ 0 & 0 & 0 & 0 & 1 & 0 \\ 0 & 0 & 0 & 0 & 0 & 0\end{array}$

Oven against toaster, $104^{\circ} \mathrm{C}$

Heat duration (oven):

Heat duration (toaster):

Preincubation:

Preincubation*heat duration:

$$
\begin{array}{lll}
P \leq 0.01 & P \leq 0.01 & P \leq 0.01 \\
& & P \leq 0.05 \\
P \leq 0.01 & P \leq 0.01 & P>0.05 \\
P>0.05 & P \leq 0.05 & P>0.05
\end{array}
$$


Tubers of $C$. esculentus could also survive heat treatment at $75^{\circ} \mathrm{C}$. Preincubation time and duration of heat treatment also affected the results for this species at $75{ }^{\circ} \mathrm{C}$. At temperatures above $75^{\circ} \mathrm{C}$, tubers of this species also did not survive except for $1 \%$ in one case (at $90{ }^{\circ} \mathrm{C}$ ).

With seeds of $A$. theophrasti, the effects of heat treatments at $90^{\circ} \mathrm{C}$ did not differ from treatments at $75^{\circ} \mathrm{C}$. The effect of heat treatments at $104{ }^{\circ} \mathrm{C}$ differed from treatments at $90{ }^{\circ} \mathrm{C}$. Treatments at $104{ }^{\circ} \mathrm{C}$ in the toaster resulted in less vitality than treatments at the same temperature in the oven. Preincubation time had no effect on the results for $A$. theophrasti. The duration of the heat treatment only influenced the treatments at $104{ }^{\circ} \mathrm{C}$ in the toaster.

\section{Discussion}

Propagules of seven plant species, which had been at least 1 day preincubated in pig slurry, were submitted to heat treatments of short duration in the range from 50 to $104^{\circ} \mathrm{C}$. The experiments were designed in such a way, that conclusions on heat-sensitivity of each species could be drawn from at least two different experiments.

For four of the weed species, the heat sensitivity of their seeds had been tested previously, but the conditions before or during the testing were different from ours. Not unexpectedly, our results were different too. Maun (1977) found that a fraction of the seeds of E. crus-galli survived $1 \mathrm{~h}$ at $130^{\circ} \mathrm{C}$ in an oven. Under the same heating conditions, our seeds of E. crus-galli were inactivated already after 3-6 min at $90^{\circ} \mathrm{C}$. A basic difference in conditions was that Maun heated dry seeds, whereas we incubated the seeds 1 day in pig slurry prior to the heat treatments. Seeds of $E$. crus-galli and tubers of $C$. esculentus became even more sensitive to the heat treatments at $75^{\circ} \mathrm{C}$ if they were preincubated longer than 1 day in the slurry.

Hopkins (1934) preincubated seeds 1 day at $50 \%$ RH. Seeds of $A$. retroflexus and $C$. album were less heat-sensitive than under our conditions ( 1 day preincubation in pig slurry). A comparison of the results of Hopkins (1934) on A. fatua with those of Metz (1970) with dry seeds of the same species also strongly suggests that the heat sensitivity of seeds is increased by preincubation in a humid atmosphere.

Horowitz \& Taylorson (1984) established that seeds of $A$. theophrasti were killed after heating at temperatures between 70 and $100^{\circ} \mathrm{C}$. Their relatively long heat duration of 1 hour probably explains the difference with our results on the same species. They also demonstrated, that seeds that easily imbibe and germinate were much more heat-sensitive than hard-scaled, dormant seeds. In our experiments, a fraction of the $A$. theophrasti seeds (45-50\%) was not affected after $15 \mathrm{~min}$ at $100{ }^{\circ} \mathrm{C}$ (Exp. 1), and after 3 and $6 \mathrm{~min}$ at $104^{\circ} \mathrm{C}$ (Exp. 4) in the oven. However, another fraction of the seeds was already inactivated at $75^{\circ} \mathrm{C}$. Lack of dormancy of the latter seeds may explain their greater heat sensitivity. Longer than 1 day preincubation in slurry did not influence the effect of heating. Viability of $A$. theophrasti seeds was greatly reduced after heating at $104{ }^{\circ} \mathrm{C}$ in a 
pressure vessel (toaster). The most relevant difference from the heat treatments in the oven probably was the presence of steam, which enables better transmission of heat to the core of the seeds than the dry air in the oven. Nearly all seeds were inactivated after 6 minutes in the toaster.

The results have shown that weed propagules can be inactivated by heat treatments of short duration. For most species, heating the seeds or tubers a few minutes at $90^{\circ} \mathrm{C}$ will be sufficient. However, to guarantee that all weed propagules in manure, even those of the most resistant species, are inactivated by heat treatment, temperatures above $100^{\circ} \mathrm{C}$ will be needed.

\section{References}

Atkeson, F.W., H.W. Hulbert \& T.R. Warren, 1934. Effect of bovine digestion and of manure storage on the viability of weed seeds. Journal of the American Society of Agronomy 26: 390-397.

Burton, G.W. \& J.S. Andrews, 1948. Recovery and viability of seeds of certain southern grasses and Lespedeza passed through the bovine digestive tract, Journal of Agricultural Science (Cambridge) 76: 94-103.

Elema, A.G., C.M.J. Bloemhard \& P.C. Scheepens, 1990. Risk-analysis for the dissemination of weeds by liquid cattle manure. Mededelingen Faculteit Landbouwwetenschappen Rijksuniversiteit Gent 55: 1203-1208.

Hopkins, C.Y., 1936. Thermal death point of certain weed seeds. Canadian Journal of Research 12: 178-183.

Horowitz, M. \& R.B. Taylorson 1984. Hardseededness and germination of velvetleaf (Abutilon theophrasti) as affected by temperature and moisture, Weed Science 32: 111-115.

MacKay, D.W., 1972. The measurement of viability. In: E.H. Roberts (Ed.), Viability of seeds, p. 173-201. Chapman \& Hall, London.

Maun, M.A. 1977. Response of seeds to dry heat. Canadian Journal of Plant Science 57: 305-307.

Metz, R., 1970. The dispersal of wild oat (Avena fatua) seeds, and possibilities to destroy and remove wild oat ears by farm sanitation (In German). Nachrichtenblatt für den Deutschen Pflanzenschutzdienst Berlin 24: 85-88.

Rieder, G., 1966. The influence of slurry on the disperal of weeds, and the application of the tetrazolium-method on weed seeds (In German). Dissertation Hohenheim Hochschule, FRG, 119 pp.

Scherer, R. \& H.D. Kutzbach, 1980. The conductivity for heat and temperature of grain fruits (In German). Grundlagen der Landtechnik 30: 21-27.

Takabayashi, M., T. Kubota \& H. Abe, 1979. Dissemination of weed seeds through cow feces. Japan Agricultural Research Quarterly 13: 204-207. 